CZASOPISMO INŻYNIERII LADDOWEJ, ŚRODOWISKA I ARCHITEKTURY

JOURNAL OF CIVIL ENGINEERING, ENVIRONMENT AND ARCHITECTURE

JCEEA, t. XXXII, z. 62 (3/I/15), lipiec-wrzesień 2015, s. 219-232

\author{
Aneta KIEBALA ${ }^{1}$ \\ Marcin KOZIEL ${ }^{2}$ \\ Małgorzata TELECKA ${ }^{3}$ \\ Wojciech ZGLOBICKI ${ }^{4}$
}

\title{
WIELOWYMIAROWA ANALIZA STATYSTYCZNA METALI CIĘŻKICH W PYLE DROGOWYM NA OBSZARZE LUBLINA
}

\begin{abstract}
W pracy określono koncentrację, $\mathrm{Co}, \mathrm{Cr}, \mathrm{Cu}, \mathrm{Hg}, \mathrm{Ni}, \mathrm{Pb}, \mathrm{V}, \mathrm{Zn}$ w 49 próbach pyłu drogowego pobranego z nawierzchni tras komunikacyjnych Lublina. Wykorzystano metody statystyczne takie jak: analiza głównych składowych, grupowanie, analizy korelacji do określenia potencjalnych źródeł badanych pierwiastków. Próby charakteryzowały się różnym stopniem zanieczyszczenia metalami śladowymi. Najbardziej wyraźne przekroczenia tła geochemicznego stwierdzono w przypadku $\mathrm{Cu}$ i Cr średnie koncentracje to odpowiednio $63 \mathrm{mg} / \mathrm{kg}$ i $51 \mathrm{mg} / \mathrm{kg}$. Natomiast zawartości zbliżone do naturalnych występowały dla $\mathrm{Co}, \mathrm{V}$ i Hg, odpowiednio 6,8 i $0,03 \mathrm{mg} / \mathrm{kg}$. Nie stwierdzono wyraźnych pozytywnych korelacji pomiędzy natężeniem ruchu samochodowego w miejscach poboru prób a zawartością badanych pierwiastków. Na podstawie analiz statystycznych dokonano podziału metali śladowych na grupy charakteryzujące się różnym pochodzeniem: bezpośrednie źródła antropogeniczne (głównie ruch samochodowy) oraz źródła naturalne (gleby).
\end{abstract}

Słowa kluczowe: analiza głównych składowych, metoda grupowania, pył drogowy, metale śladowe, Lublin

\section{Wprowadzenie}

Jednym z istotnych źródeł zanieczyszczenia powietrza i gleb w miastach jest pył drogowy (street dust). Tworzą go cząstki cząstki mineralne i organiczne składnikami pyłu drogowego są powszechnie występujące minerały takie jak

${ }^{1}$ Autor do korespondencji/corresponding author: Aneta Kiebała, Uniwersytet Marii Curie Skłodowskiej, Al. Kraśnicka 2CD, 20-718 Lublin, tel. 81 5736897, aneta.kiebala@poczta.umcs.lublin.pl

${ }^{2}$ Marcin Kozieł, Uniwersytet Marii Curie Skłodowskiej, Al. Kraśnicka 2CD, 20-718 Lublin, tel. 81 5376802, marcin.koziel@ poczta.umcs.lublin.pl

${ }^{3}$ Małgorzata Telecka, Uniwersytet Marii Curie Skłodowskiej, Al. Kraśnicka 2CD, 20-718 Lublin, tel. 81 5736886, m.telecka@poczta.umcs.lublin.pl

${ }^{4}$ Wojciech Zgłobicki, Uniwersytet Marii Curie Skłodowskiej, Al. Kraśnicka 2CD, 20-718 Lublin, tel. 81 5736884, wojciech.zglobicki@umcs.pl 
akumulowane na powierzchni tras komunikacyjnych pochodzące z emitorów przemysłowych, ruchu samochodowego oraz źródeł naturalnych. Głównymi są kwarc czy skalenie. Są w nim również obecne różnego rodzaju związki toksyczne, w tym metale ciężkie. Głównym ich źródłem jest emisja spalin z silników samochodowych oraz ścieranie się różnych elementów pojazdów (opony, tarcze hamulcowe) $[4,14,13]$. Elementem pyłu drogowego są również cząstki mineralne pochodzące $\mathrm{z}$ gleb oraz wysypywanego zimą na powierzchnię dróg piasku. Zanieczyszczenia, gromadzące się $\mathrm{w}$ pyle drogowym są wyjątkowo groźne ze względu na możliwość ich wtórnego uruchamiania i występowanie na niewielkich wysokościach, w strefie życia ludzi, roślin i zwierząt. Metale śladowe mogą w ten sposób dostawać się do organizmów ludzi i stanowić poważne zagrożenia dla ich zdrowia $[1,23]$.

Prowadzone $\mathrm{w}$ wielu miastach badania wskazują na podwyższone koncentracje metali śladowych $w$ pyle drogowym $[2,5,18]$. W Polsce problematyka ta nie jest szczególnie często podejmowana. Opublikowano do tej pory niewielką liczbę prac dotyczących zawartości metali śladowych w pyle drogowym [20], $[21,18,10]$. Znacznie częściej podejmowano badania dotyczące stopnia zanieczyszczenia gleb w pobliżu tras komunikacyjnych $[16,17]$.

Celem pracy była ocena stopnia wzbogacenia pyłu drogowego metalami ciężkimi oraz próba wskazania źródeł ich pochodzenia na podstawie wyników wielowymiarowej analizy statystycznej.

\section{Obszar i metoda badań}

Lublin położony jest w północno-zachodniej części Wyżyny Lubelskiej. Zajmuje powierzchnię 147,5 $\mathrm{km}^{2}$, zamieszkałą przez 347,6 tys. mieszkańców (Województwo Lubelskie. Podregiony. Powiaty. Gminy 2014). Naturalną osią miasta jest dolina rzeki Bystrzycy (lewobrzeżny dopływ Wieprza), która dzieli go na dwa obszary. Każdy z nich obejmuje po dwa mezoregiony - na zachodzie są to: Płaskowyż Nałęczowski i Równina Bełżycka, na wschodzie: - Płaskowyż Łuszczowski i Wyniosłość Giełczewska [11]. Największe deniwelacje, dochodzące nawet do 40 metrów, notowane są w obrębie Płaskowyżu Nałęczowskiego. Występuje tu gęsta sieć głębokich, suchych dolin uchodzących do większych dolin o stałym odwodnieniu. W pozostałej części miasta (Równina Bełżycka, Płaskowyż Świdnicki i Wyniosłość Giełczewska) deniwelacje są znacznie mniejsze (dochodzą do kilkunastu metrów). System rzeczny Lublina tworzą Bystrzyca oraz jej dopływy: lewobrzeżny - Czechówka (o przebiegu równoleżnikowym), i prawobrzeżny - Czerniejówka (o przebiegu południkowym). Są to rzeki średniej długości $(20-70 \mathrm{~km})$. Średnia, roczna temperatura powietrza w Lublinie wynosi $+8,0^{\circ} \mathrm{C}$. Średnia roczna suma opadów wynosi ok. $650 \mathrm{~mm}$. Średnia prędkość wiatru w Lublinie nie jest duża i wynosi $2,7 \mathrm{~m} / \mathrm{s}$. Zaznacza się wyraźna przewaga wiatrów z sektora południowo-zachodniego (S, SW, W) [6]. Dominującym typem gleb są powstałe na lessach gleby płowe i brunatne 
w części zachodniej miasta, mady w dnie doliny Bystrzycy oraz brunatne i bielicowe w części wschodniej.

Tereny przemysłowe koncentrują się głównie we wschodniej części miasta. Do najważniejszych zakładów należą Elektrociepłownia Lublin-Wrotków, zakłady URSUS, fabryka maszyn rolniczych Sipma. Działają tu również liczne zakłady przemysłu spożywczego, farmaceutyczne, chemiczne i budowlane. Należy podkreślić, że gleby miasta nie wykazują znaczącego zanieczyszczenia metalami ciężkimi [16].

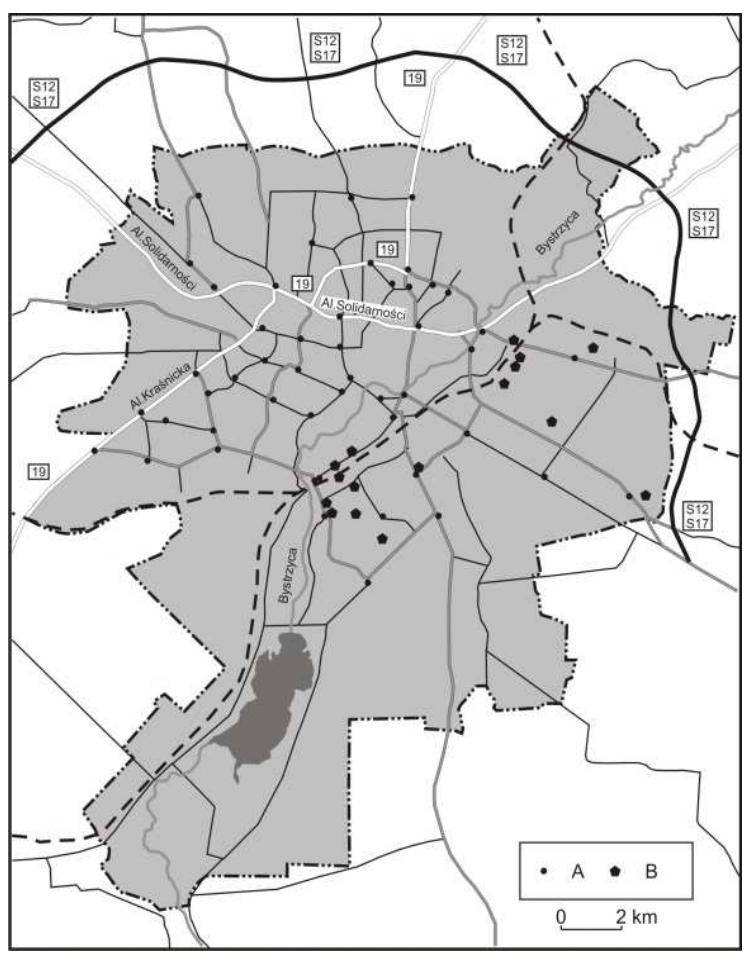

Rys. 1. Położenie punktów poboru próbek; A - próby, B obiekty przemysłowe

Fig. 1. Study area and sample sites in Lublin; A - samples, $\mathrm{B}$ - industrial plants

Punkty poboru próbek położone były w obrębie tras komunikacyjnych, charakteryzujących się zróżnicowanym natężeniem ruchu samochodowego. Ogółem analizowano próby pochodzące z 49 punktów (rys. 1), które były rozmieszczone w pobliżu dzielnic mieszkaniowych, centrów handlowousługowych oraz terenów przemysłowych. Większość z punktów zlokalizowana była w zachodniej części miasta. Dla 41 punktów poboru prób dysponowano danymi dotyczącymi natężenia ruchu pojazdów w godzinach 15-16 i 16-17. Materiał do badań pochodził z nawierzchni dróg, przy jej krawędzi, w miej- 
scach gromadzenia się pyłu drogowego, w miesiącach luty-marzec 2013. Próbki były pobierane za pomocą łopatki do plastikowych woreczków a następnie osuszone w temperaturze pokojowej oraz przesiane przez sita $1 \mathrm{~mm}$ oraz $200 \mu \mathrm{m}$. $\mathrm{W}$ pracy analizowano zawartość pierwiastków w materiale frakcji $<200 \mu \mathrm{m}$. Preparaty do analiz przygotowano w postaci pastylek prasowanych po wcześniejszym zmieleniu materiału w cyrkonowym młynku kulowym. Analizy koncentracji: $\mathrm{Co}, \mathrm{Cr}, \mathrm{Cu}, \mathrm{Ni}, \mathrm{Pb}, \mathrm{V}, \mathrm{Zn}$ wykonano na spektrometrze fluorescencji rentgenowskiej z dyspersją energii (EDXRF, Epsilon5 Panalytical). Zawartość Hg określono przy pomocy spektrometru AMA-254. Poprawność oznaczeń zweryfikowano na podstawie oznaczeń certyfikowanych materiałów referencyjnych. Błąd pomiaru wynosił 1-3 \% dla analiz EDXRF oraz AMA 254.

W pracy została wykorzystana analiza korelacji Pearsona, metoda głównych składowych (principal component analysis - PCA) i metoda grupowania (cluster analysis - CA). Współczynniki korelacji wskazują na siłę wzajemnych relacji pomiędzy dwoma metalami, natomiast PCA i CA są powszechnie stosowanymi w badaniach środowiskowych metodami wielowymiarowymi metodami statystycznymi pozwalającymi na wyznaczanie grup pierwiastków o podobnych cechach [13], [22]. CA pozwala na zgrupowanie pierwiastków po cechach o zbliżonych wartościach, natomiast PCA - o cechach o podobnych własnościach. Metody te nie są równoważne, tylko komplementarne. Zastosowanie wymienionych metod pozwoli na wskazanie źródeł pochodzenia badanych metali. Obliczenia wykonano za pomocą programu Mathematica.

Analiza głównych składowych pozwala na zredukowanie liczby zmiennych opisujących dany obiekt, a także na wskazanie, jaki wpływ mają zmienne pierwotne na składowe główne i jakie są wzajemne korelacje zmiennych pierwotnych. W analizowanym przypadku występuje 10 zmiennych opisujących każdą z badanych prób.

Metoda grupowania pozwala na wydzielenie grup obiektów opierając się na zróżnicowaniu zmiennych. W celu wykonania grupowania konieczne było wykorzystanie metody pozwalającej na utworzenie grup obiektów w 10-wymiarowej przestrzeni. Graficzną prezentacją wielowymiarowej analizy skupień są dendrogramy. Do obliczenia odległości pomiędzy poszczególnymi klastrami została wykorzystana metoda Warda. W pracy przeprowadzono grupowanie na podstawie danych określających wielkość przekroczenia tła geochemicznego dla każdego z pierwiastków (a nie na wartościach bezwzględnych zawartości).

\section{Wyniki}

Analizowane próby pyłu drogowego charakteryzują się zróżnicowanym stopniem antropogenicznego wzbogacenia w badane pierwiastki śladowe (Tabela 1). Największy stopień zanieczyszczenia stwierdzono w przypadku $\mathrm{Cu}$ i $\mathrm{Cr}$. Średnie koncentracje tych metali przekraczają tło geochemiczne odpowiednio 6 i 5 razy (maksymalne przekroczenia: 13 i 7 razy). Badany pył drogowy cecho- 
wał się nieznacznym wzbogaceniem w Pb, Ni i Zn (średnie koncentracje 2-2,5 razy wyższe w stosunku do tła). Zawartość zbliżoną do naturalnej stwierdzono dla Co, V i Hg. W przypadku jednej próbki odnotowano znacznie wyższą koncentrację $\mathrm{Hg}(0,48 \mathrm{mg} / \mathrm{kg})$. Koncentracje maksymalne wszystkich pierwiastków, za wyjątkiem Co i Hg, były co najmniej dwa razy wyższe od tła geochemicznego. Średnie zawartości analizowanych metali w próbkach pyłu drogowego $w$ stosunku do wartości tha maleją następująco: $\mathrm{Cu}>\mathrm{Cr}>\mathrm{Ni}>\mathrm{Zn}>\mathrm{Pb}>\mathrm{Mn}>\mathrm{Co}>\mathrm{V}>\mathrm{Hg}$.

Tabela 1. Koncentracje metali śladowych w pyle drogowym Lublina

Table 1. Trace metal concentrations in street dust in Lublin

\begin{tabular}{|c|c|c|c|c|c|c|c|c|c|c|}
\hline & Co & Cr & Cu & Hg & Mn & Mo & Ni & Pb & V & Zn \\
\hline Mean & 5,5 & 52,8 & 65,7 & 0,03 & 378,8 & 3,8 & 26,8 & 23,3 & 7,9 & 201,8 \\
\hline GM & 5,5 & 51,2 & 59,2 & 0,02 & 378,9 & 3,8 & 26,3 & 22,0 & 3,3 & 190,0 \\
\hline Median & 5,6 & 53,1 & 65,7 & 0,03 & 381,1 & 3,8 & 27,7 & 22,5 & 8,3 & 219,7 \\
\hline SD & 0,4 & 9,0 & 28,5 & 0,02 & 23,7 & 0,5 & 4,8 & 8,9 & 4,9 & 64,7 \\
\hline Min & 4,6 & 26,4 & 12,8 & 0,003 & 305,2 & 2,6 & 13,9 & 9,8 & 0,0 & 64,0 \\
\hline Max & 6,2 & 72,8 & 132,4 & 0,48 & 422,0 & 5,0 & 36,3 & 71,3 & 21,6 & 341,7 \\
\hline CV & 0,07 & 0,17 & 0,43 & 0,66 & 0,06 & 0,13 & 0,18 & 0,38 & 0,62 & 0,32 \\
\hline Skośność & $-0,55$ & $-0,30$ & 0,54 & 0,50 & $-0,81$ & $-0,25$ & $-0,41$ & 3,17 & 0,05 & $-0,06$ \\
\hline Tło $^{1}$ & 5 & 10 & 10 & 0,05 & 250 & 1,5 & 10 & 12,5 & 10 & 100 \\
\hline
\end{tabular}

1 - Lis, Pasieczna (1995) [9]; w przypadku Hg z większości obliczeń wyłączono jedną próbę o bardzo wysokiej zawartości tego pierwiastka

Tabela 2. Porównanie koncentracji metali ciężkich $(\mathrm{mg} / \mathrm{kg})$ w pyle drogowym w wybranych miastach

Table 2. Comparison of heavy metal concentrations ( $\mathrm{mg} / \mathrm{kg}$ ) in street dust in chosen cities

\begin{tabular}{|ccccccccccc|}
\hline Lokalizacja & Co & Cr & Cu & Hg & Mn & Ni & Pb & V & Zn & Źródło \\
\hline $\begin{array}{l}\text { Warszawa } \\
\text { Zielona }\end{array}$ & - & - & 31 & - & - & 10 & 34 & - & 64 & {$[10]$} \\
Góra & - & - & $12-264$ & - & - & - & - & - & $20-$ & {$[18]$} \\
\hline Oslo & 19 & - & 123 & - & 833 & 41 & 180 & - & 412 & {$[6]$} \\
Madryt & 3 & 61 & 188 & - & 362 & 44 & 1927 & 17 & 467 & {$[6]$} \\
Avilés & 7.03 & 41.6 & $104-$ & 2.56 & 1661 & 27.5 & 514 & 28.1 & 2422 & {$[15]$} \\
Xi`an & - & 167,3 & 95 & 0,64 & 687 & - & 230,5 & - & 421,5 & {$[7]$} \\
Pekin & 15,9 & 126,7 & 123,2 & 1,1 & 804,2 & 48,8 & 433,2 & 88,9 & 715,3 & {$[13]$} \\
\hline ,-,, brak danych & & & & & & & & & \\
\end{tabular}

Największe zróżnicowanie (koncentracji, wysokie wartości CV), występowało w przypadku $\mathrm{Hg}, \mathrm{V}, \mathrm{Cu}, \mathrm{Pb}$ i Zn, zaś najmniejsze dla Co, Mn, Cr i Ni (Tabela 1). Mediana i średnia arytmetyczna były dla badanych metali podobne. Część metali śladowych $(\mathrm{Cu}, \mathrm{Hg}$ i $\mathrm{Pb})$ cechuje się prawostronną skośnością (przeważają próby poniżej średniej). Jest ona najbardziej widoczna w przypadku Pb. Wyraźna lewostronna skośność występuje dla Mn, Ni, Co i Cr. 
Średnie zawartości analizowanych metali ciężkich w próbkach pyłu drogowego w Lublinie w porównaniu z koncentracjami w innych miastach kształtują się na umiarkowanym lub niskim poziomie (Tabela 2). Zawartości większości metali są zbliżone do koncentracji w innych miastach europejskich (Oslo, Madryt, Avilés), jednocześnie są wyraźnie niższe od zawartości w dużych aglomeracjach przemysłowych (Pekin, Xi`an).

Analiza PCA pokazuje, że najbardziej istotna jest pierwsza składowa główna, która tłumaczy ponad $60 \%$ zmienności, druga składowa tłumaczy $10 \%$, a trzecia 7,6\% zmienności (Tabela 3). Daje to razem 79,17\% zmienności.

Tabela. 3. Tabela zmienności wyjaśnianej przez poszczególne składowe główne

Table. 3. Table of variation explained by individual principal components

\begin{tabular}{|c|c|c|c|c|c|c|c|c|c|}
\hline $\begin{array}{c}\text { Składowe } \\
\text { główne }\end{array}$ & $\mathbf{1}$ & $\mathbf{2}$ & $\mathbf{3}$ & $\mathbf{4}$ & $\mathbf{5}$ & $\mathbf{6}$ & $\mathbf{7}$ & $\mathbf{8}$ & $\mathbf{9}$ \\
\hline $\begin{array}{c}\text { Wartości wła- } \\
\text { sne }\end{array}$ & 5,47 & 0,96 & 0,68 & 0,63 & 0,46 & 0,30 & 0,20 & 0,18 & 0,09 \\
\hline $\begin{array}{c}\text { Udział w wa- } \\
\text { riancji (\%) }\end{array}$ & 60,77 & $\begin{array}{c}10,7 \\
6\end{array}$ & 7,63 & 7,01 & 5,16 & 3,36 & 2,25 & 2,01 & 1,00 \\
\hline $\begin{array}{c}\text { Sumaryczny } \\
\text { udział w wa- } \\
\text { riancji (\%) }\end{array}$ & 60,77 & $\begin{array}{c}71,5 \\
4\end{array}$ & $\begin{array}{c}79,1 \\
7\end{array}$ & $\begin{array}{c}86,1 \\
9\end{array}$ & $\begin{array}{c}91,3 \\
6\end{array}$ & $\begin{array}{c}94,7 \\
3\end{array}$ & $\begin{array}{c}96,9 \\
8\end{array}$ & $\begin{array}{c}98,9 \\
9\end{array}$ & 100 \\
\hline
\end{tabular}

Tabela. 4. Udział poszczególnych składowych pierwotnych (metali) w zmienności trzech składowych głównych

Table. 4. Content of particular initial components (metals) in variation of three main principal components

\begin{tabular}{|c|c|c|c|c|c|c|}
\hline & \multicolumn{7}{|c|}{ Składowe główne } \\
\cline { 2 - 7 } & $\mathbf{1}$ & $\mathbf{2}$ & $\mathbf{3}$ & $\mathbf{4}$ & $\mathbf{5}$ & $\mathbf{6}$ \\
\hline $\mathbf{M n}$ & $\mathbf{- 0 . 9 1 6}$ & -0.139 & -0.076 & 0.039 & 0.071 & -0.200 \\
\hline $\mathbf{V}$ & $\mathbf{- 0 . 8 2 1}$ & -0.246 & -0.311 & 0.329 & 0.066 & -0.051 \\
\hline $\mathbf{C r}$ & $\mathbf{- 0 . 7 3 4}$ & -0.013 & 0.234 & -0.392 & $\mathbf{0 . 4 9 5}$ & 0.012 \\
\hline $\mathbf{N i}$ & $\mathbf{- 0 . 8 8 5}$ & -0.033 & -0.222 & 0.153 & 0.113 & 0.048 \\
\hline $\mathbf{C u}$ & $\mathbf{- 0 . 7 6 1}$ & 0.318 & -0.041 & -0.396 & -0.319 & -0.051 \\
\hline $\mathbf{Z n}$ & $\mathbf{- 0 . 8 8 2}$ & -0.016 & 0.019 & -0.091 & -0.217 & -0.225 \\
\hline $\mathbf{P b}$ & -0.626 & -0.160 & $\mathbf{0 . 6 8 5}$ & 0.295 & -0.128 & 0.024 \\
\hline $\mathbf{C o}$ & $\mathbf{- 0 . 8 5 7}$ & -0.102 & -0.086 & -0.077 & -0.132 & $\mathbf{0 . 4 5 0}$ \\
\hline Hg & -0.381 & $\mathbf{0 . 8 6 5}$ & 0.026 & 0.290 & 0.1163 & 0.028 \\
\hline
\end{tabular}

Podkreślono wskaźniki o wartościach powyżej 0,4

Analiza wykresu osypiska wskazuje, że pierwsza składowa jest dominująca, a pozostałe można odrzucić. $\mathrm{W}$ badanym przypadku można również uwzględnić trzy główne składowe, gdzie pierwsza jest zdeterminowana głównie przez Mn, Zn, $\mathrm{Ni}$, Co i w nieco mniejszym stopniu $\mathrm{V}$, druga przez $\mathrm{Hg}$, a trzecia, choć w mniejszym stopniu, przez $\mathrm{Pb}$ (Tabela 4 i rys. 2). Cr i Cu można zaliczyć do czwartej grupy, która ma mniejszy (rzędu -0,7) wpływ na pierwszą składową główną. 


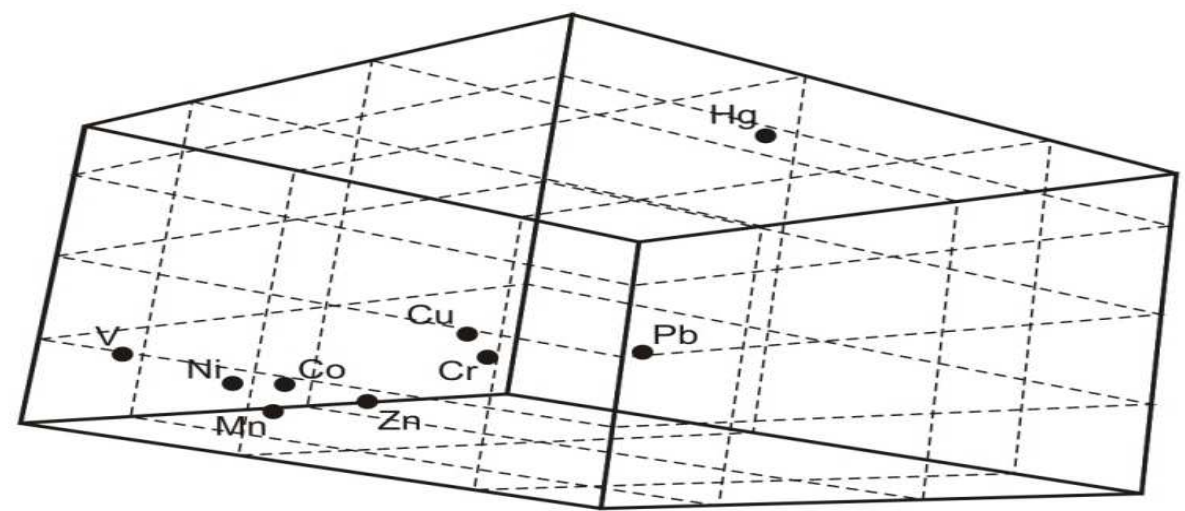

Rys. 2. Trójwymiarowy rzut składowych pierwotnych na trzy składowe główne

Fig. 2. Three-dimension projection of initial components on three principal components

Współczynniki korelacji liniowej Pearsona dla badanych metali śladowych zawiera Tabela 5. Analiza korelacji potwierdza wyniki PCA. Metale z czwartego okresu, czyli Mn, Zn, Ni, Co i V są ze sobą silnie skorelowane (najsilniejsze korelacje występują między Mn i V, Mn i Zn i między V i Ni). Należy jednak zauważyć, że mimo, iż $\mathrm{V}$ wykazuje silne korelacje aż z trzema pierwiastkami i z trzema korelację średnią, to zawartość tego pierwiastka w $67 \%$ prób jest niższa tła, co potwierdzają wyniki PCA, dla których wpływ V na pierwszą składową główną, choć silny, jest mniejszy niż dla $\mathrm{Zn}$. Mn, i Ni. Cr, Pb i Cu wykazują korelacje średnie, rzadziej silne.

Metoda grupowania pozwoliła na wydzielenie trzech grup (rys. 3). Pierwsza grupa $(\mathrm{Cu}$ i $\mathrm{Cr})$ wykazuje bardzo silne odchylenia od średniej wartości (średnio o 500\%), druga ( $\mathrm{Pb}, \mathrm{Zn}, \mathrm{Ni}$ ) - średnie odchylenia około $200 \%$, i trzecia (Mn, V, Co, Hg) - średnie odchylenia około $100 \%$. W trzeciej grupie pojawiają się dwa pierwiastki (Hg i V), których zawartości w większości przypadków nie przekraczają tła.

Tabela 5. Współczynniki korelacji Pearsona

Table 5. Pearson`s correlation coefficients

\begin{tabular}{|c|c|c|c|c|c|c|c|c|c|}
\hline & Co & $\mathbf{C r}$ & $\mathbf{C u}$ & $\mathbf{H g}$ & $\mathbf{M n}$ & $\mathbf{N i}$ & $\mathbf{P b}$ & $\mathbf{V}$ & $\mathbf{Z n}$ \\
\hline Co & 1 & & & & & & & & \\
\hline $\mathbf{C r}$ & 0,58 & 1 & & & & & & & \\
\hline $\mathbf{C u}$ & $\mathbf{0 , 6 4}$ & 0,54 & 1 & & & & & & \\
\hline $\mathbf{H g}$ & 0,22 & 0,22 & 0,39 & 1 & & & & & \\
\hline $\mathbf{M n}$ & $\mathbf{0 , 7 2}$ & 0,66 & 0,63 & 0,24 & 1 & & & & \\
\hline $\mathbf{N i}$ & $\mathbf{0 , 7 3}$ & 0,58 & 0,58 & 0,33 & $\mathbf{0 , 7 8}$ & 1 & & & \\
\hline $\mathbf{P b}$ & 0,48 & 0,44 & 0,33 & 0,18 & 0,54 & 0,45 & 1 & & \\
\hline $\mathbf{V}$ & $\mathbf{0 , 7 0}$ & 0,44 & 0,43 & 0,19 & $\mathbf{0 , 8 2}$ & $\mathbf{0 , 8 1}$ & 0,43 & 1 & \\
\hline $\mathbf{Z n}$ & $\mathbf{0 , 7 1}$ & 0,58 & $\mathbf{0 , 7 1}$ & 0,27 & $\mathbf{0 , 7 8}$ & $\mathbf{0 , 7 2}$ & 0,54 & 0,67 & 1 \\
\hline
\end{tabular}




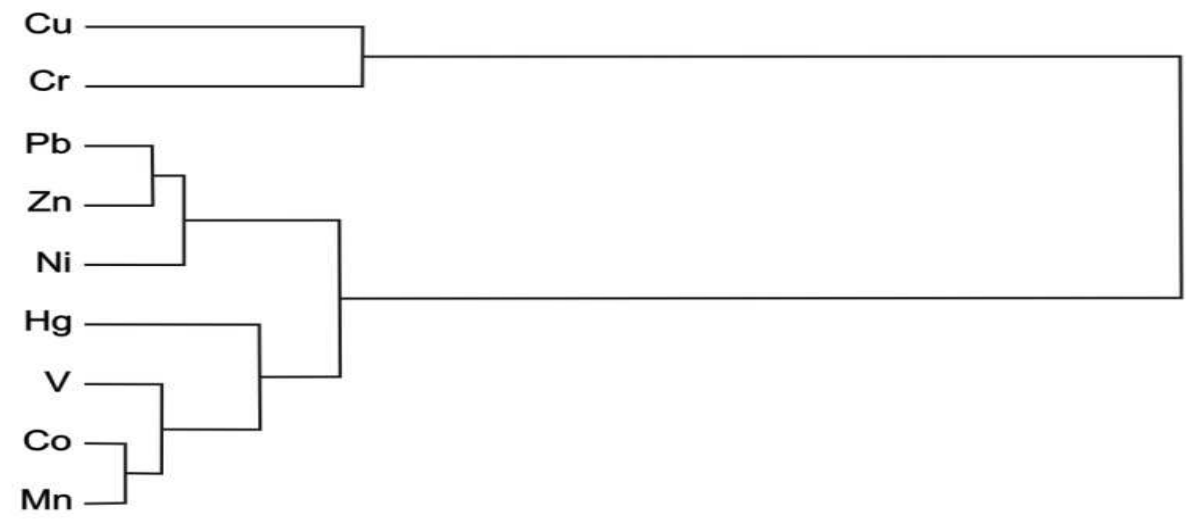

Rys. 3. Dendrogram - prezentacja wyników grupowania metodą Warda 10 badanych metali

Fig. 3. Dendrogram - presentation of results of Ward grouping method for 10 analysed metals

Na podstawie analizy CA i PCA można wydzielić pięć grup metali o zbliżonych korelacjach i odchyleniach zawartości metali od tła:

- Grupa 1: $\mathrm{Cr}$ i $\mathrm{Cu}$ - znaczące przekroczenia tła (5-6 razy), średnia korelacja z pozostałymi metalami

- Grupa 2: $\mathrm{Pb}$ - średnio dwukrotne przekroczenie tła i słaba lub średnia korelacja z pozostałymi metalami

- Grupa 3: Zn i Ni - dwu, trzykrotne przekroczenie i silna korelacja $\mathrm{z}$ większością pozostałych metali

- Grupa 4: Mn, Co, V - zawartości na poziomie tła i silna lub średnia korelacja z większością pozostałych metali

- Grupa 5: Hg - brak większych odchyleń od tła, brak korelacji z pozostałymi metalami.

Średnie natężenie ruchu samochodowego w badanych punktach to 1000 pojazdów na godzinę. Wartość ta zmieniała się od 711 do 2520 samochodów. W zdecydowanej większości punktów natężenie ruchu pojazdów w badanych godzinach wynosiło od 50 do 1000 pojazdów.

Tabela 6. Wskaźniki korelacji pomiędzy natężeniem ruchu samochodowego a koncentracją badanych metali

Table 6. Correlation between traffic intensity and heavy metals concentrations

\begin{tabular}{|c|c|c|c|c|c|c|c|c|}
\hline $\mathrm{Co}$ & $\mathrm{Cr}$ & $\mathrm{Cu}$ & $\mathrm{Hg}$ & $\mathrm{Mn}$ & $\mathrm{Ni}$ & $\mathrm{Pb}$ & $\mathrm{V}$ & $\mathrm{Zn}$ \\
\hline 0,23 & 0,12 & 0,06 & 0,10 & 0,16 & 0,07 & 0,14 & $-0,06$ & 0,35 \\
\hline
\end{tabular}




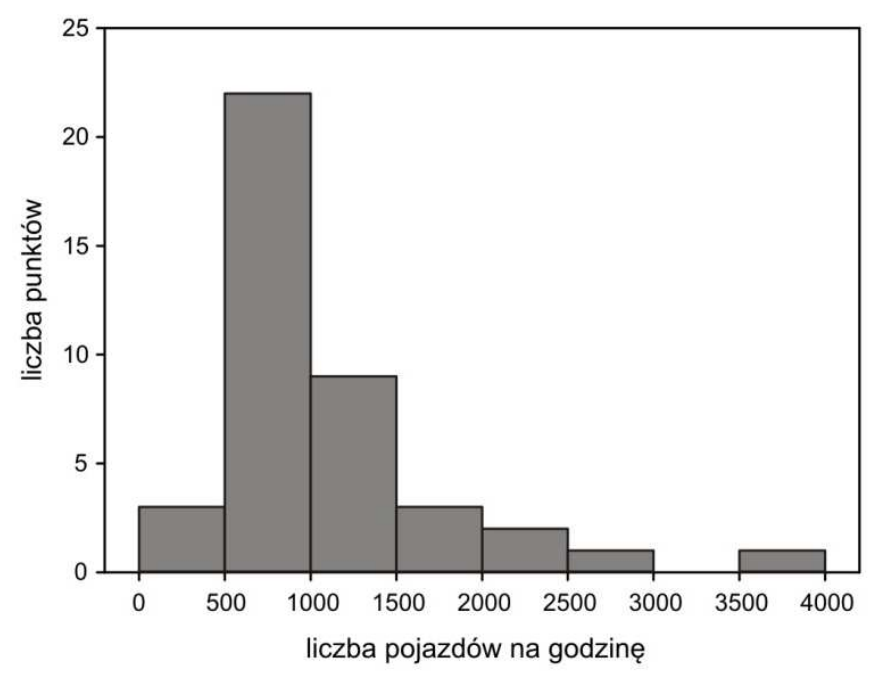

Rys. 4. Natężenie ruchu samochodów

Fig. 4. Road traffic intensity

Nie stwierdzono wyraźnej liniowej zależności pomiędzy koncentracjami a natężeniem ruchu samochodowego. Jedynym wyjątkiem jest Zn, dla którego występuje średnia korelacja dodatnia. Analiza rozkładu przestrzennego maksymalnych koncentracji wskazuje jednak na pewne prawidłowości. Występują one zazwyczaj na skrzyżowaniach charakteryzujących się z jednej strony dość dużym natężeniem ruchu przy jednoczesnej tendencji do tworzenia się korków w godzinach szczytu (Rondo Krwiodawców, okolice Placu Bychawskiego, rejon Kraśnicka-Orkana, Kunickiego-Krańcowa). Należy również podkreślić fakt, iż pył drogowy pochodzący ulic, nad którymi przebiega trakcja trolejbusowa zawierał średnio o ponad $10 \%$ więcej $\mathrm{Cu}$. Tutaj także stwierdzono maksymalne zawartości tego pierwiastka - ponad $130 \mathrm{mg} / \mathrm{kg}$.

\section{Dyskusja - identyfikacja źródeł metali (grup metali)}

Wyraźnie podwyższone koncentracje $\mathrm{Cr}, \mathrm{Cu}$ w pyle drogowym Lublina sugerują ich antropogeniczne źródło. Z kolei zawartość innych pierwiastków $(\mathrm{Co}, \mathrm{Hg}, \mathrm{Mn}, \mathrm{V})$ jest nieznacznie większa lub porównywalna $\mathrm{z}$ tłem geochemiczny co wskazuje, że pochodzą głównie ze źródeł naturalnych (gleby). Silne pozytywne korelacje (wskaźnik powyżej 0,7) występują pomiędzy: Co i Mn, Co i Ni, Co i V, Co i Zn, Cu i Zn, Mn i Ni, Mn i V, Mn i Zn, Ni i V, Ni i Zn. Pozytywne średnie korelacje $(0,5-0,7)$ stwierdzono również dla $\mathrm{Co}$ i $\mathrm{Cr}, \mathrm{Cr}$ i $\mathrm{Cu}, \mathrm{Cr}$ i $\mathrm{Mn}, \mathrm{Cr}$ i $\mathrm{Mo}, \mathrm{Cr}$ i Ni, Cr i Zn, Cu i Mn, Cu i Mo, Cu i Ni, Mn i Mo, Mn i Pb, Mo i $\mathrm{Zn}, \mathrm{Pb}$ i Zn, Zn i V. Pierwiastkiem wykazującym jedynie słabe i średnie korelacje jest rtęć. Analiza wskaźników korelacji sugeruje, wspólne źródło dla 
a) $\mathrm{Zn}, \mathrm{Mn}, \mathrm{Co}, \mathrm{Ni}, \mathrm{V}$ oraz dla b) $\mathrm{Cu}, \mathrm{Cr}$. Podobnych danych dostarczają wyniki PCA, pozwalają one na wyróżnienie trzech grup: a) $\mathrm{Mn}, \mathrm{Zn}, \mathrm{Ni}, \mathrm{Co} \mathrm{i} \mathrm{V}, \mathrm{Cr}, \mathrm{Cu}$, b) $\mathrm{Hg}, \mathrm{c}) \mathrm{Pb}$. Z grupy a) można wyodrębnić podgrupę $\mathrm{Cr}-\mathrm{Cu}$ ponieważ charakteryzuje ją nieco niższy wpływ na pierwszą składową główną odpowiednio: $-0,73$ oraz $-0,76$. $\mathrm{Z}$ kolei wyniki $\mathrm{CA}$ wskazuje na istnienie trzech grup: a) $\mathrm{Cu}$ i Cr, b) Pb, Ni, i Zn, c) Co, Hg, Mn, V (Rycina 3). Przy czym te dwie ostatnie wchodzą w skład jednej większej grupy. Syntetyczna analiza wyników wszystkich trzech metod pozwala na wyróżnienie dwóch zasadniczych źródeł pochodzenia badanych pierwiastków: a) dominujące źródło antropogeniczne $(\mathrm{Cu}$ i Cr), b) dominujące źródło naturalne (gleby): $\mathrm{Co}, \mathrm{Hg}, \mathrm{Mn}, \mathrm{Ni}, \mathrm{Pb}, \mathrm{V}, \mathrm{Zn}$.

Wydzielona w oparciu o zastosowane analizy statystyczne pierwsza grupa pierwiastków ( $\mathrm{Cu}$ i $\mathrm{Cr}$ ) charakteryzuje się bardzo silną korelacją w analizie grup związaną z istotnym przekroczeniem wartości tła. Z kolei współczynnik korelacji Pearsona dla $\mathrm{Cu}$ i $\mathrm{Cr}(0,54)$ wskazuje na korelację średnią. PCA grupuje natomiast $\mathrm{Cr}$ i $\mathrm{Cu}$ razem z $\mathrm{Mn}, \mathrm{V}, \mathrm{Ni}, \mathrm{Zn}$ i Co w pierwszej grupie składowych głównych, jednak oba te pierwiastki cechują niższe współczynniki udziału $(<0,8)$. Dodatkowo $\mathrm{Cr}$ i $\mathrm{Cu}$ w odróżnieniu od pozostałych pierwiastków charakteryzują się średnim wpływem na składową $5(0,489$ i 0,32$)$, podczas gdy pozostałe pierwiastki takiego wpływu nie wykazują. Wyniki CA, PCA oraz współczynniki korelacji Pearsona. Znaczące przekroczenie wartości tła przez $\mathrm{Cr}$ i $\mathrm{Cu}$ wskazują na antropogeniczne źródła tych pierwiastków. Zarówno $\mathrm{Cr}$ jak i $\mathrm{Cu}$ związane są z ruchem samochodowym. Cu stosowana jest powszechnie w smarach samochodowych [3]. Może również pochodzić ze zużywania się samochodowych pomp oleju lub korozji metalowych części samochodów będących w kontakcie z olejem [6], oraz zużywanie się silnika [3], [8]. Cr używana jest do produkcji części samochodowych ze stali nierdzewnej, także do produkcji stali aluminiowej oraz tytanowej [5].

Druga grupa o naturalnych źródłach obejmuje Co, $\mathrm{Hg}, \mathrm{Mn}, \mathrm{Ni}, \mathrm{Pb}, \mathrm{V}$ i Zn. Wszystkie pierwiastki charakteryzują się umiarkowanymi koncentracjami w stosunku do wartości tła, przy czym zawartości $\mathrm{Pb}, \mathrm{Ni}, \mathrm{Zn}, \mathrm{Mn}$, przekraczają tło geochemiczne ( $\mathrm{Zn}-3$ razy, $\mathrm{Pb}$ i $\mathrm{Ni}-2$ razy oraz $\mathrm{Mn}$ 1,5 razy) podczas gdy pozostałe pierwiastki $(\mathrm{Co}, \mathrm{Hg}, \mathrm{V})$ charakteryzują się koncentracją poniżej wartości tła. Współczynniki korelacji liniowej Pearsona wskazują na silne i średnie korelacje w obrębie tej grupy dla wszystkich pierwiastków oprócz Hg. Podobny podział wykazuje metoda grupowania (CA) wskazując dwie grupy z podziałem na: wspólny klaster dla $\mathrm{Pb}, \mathrm{Zn}$ i $\mathrm{Ni}$, oraz drugi klaster dla $\mathrm{Hg}$, V, Co i $\mathrm{Mn}$. Z kolei metoda składowych głównych (PCA) sugeruje wyodrębnienie trzech podgrup w obrębie grupy pierwiastków o naturalnych źródłach. Obejmują one: Mn, V, Zn, Co, Ni najsilniej wpływające na 1 składową (współczynniki powyżej 0,8); następnie Hg (mająca zasadniczy wpływ na drugą składową dla PCA) oraz $\mathrm{Pb}$ (silny wpływ na trzecią składową). Niskie (poniżej wartości tła) koncentracje Co, Hg, V wskazują na ich wyraźnie naturalny charakter. Z kolei Mn, $\mathrm{Ni}, \mathrm{Pb}$ i Zn, które przekraczają zawartości tła 2-2,5 razy mogą mieć źródło mie- 
szane, z niewielkim wpływem czynników antropogenicznych. Czynnik ten najprawdopodobniej jest związany transportem samochodowym. $\mathrm{Pb}$ pomimo wprowadzenia benzyny bezołowiowej, może pochodzić ze zdeponowanych wcześniej zanieczyszczeń w glebach miejskich, które były remobilizowane. Zn jest powszechnie używany w procesie wulkanizacji opon. Jego źródło może dodatkowo stanowić korozja galwanizowanych części samochodowych [3], [8]. Związki cynku są również stosowane, jako antyoksydant oraz detergent polepszający jakość smarów olejowych [6].

Analizując próbki pyłu drogowego na terenie Lublina pod kątem zawartości metali ciężkich i ich źródeł pochodzenia należałoby zwrócić jeszcze uwagę na fakt posypywania dróg piachem w okresie zimy. Materiał ten, prawdopodobnie nie wpływa $\mathrm{w}$ zasadniczym stopniu na zawartość zanieczyszczeń w analizowanych próbkach ze względu choćby na frakcję (analizowany materiał to frakcja $<200 \mu \mathrm{m})$ jednak stanowić może potencjalne, dodatkowe źródło. Zagadnienie to wymaga bardziej szczegółowych analiz.

W przypadku metali ciężkich w pyle drogowym Lublina wyniki wielowymiarowych analiz statystycznych nie były tak jednoznaczne jak w dla studiów dotyczących miast przemysłowych z obszaru Chin [13], [22]. Występujące różnice w wynikach CA i PCA wiązać należy naszym zdaniem z wyraźnie niższymi zawartościami badanych metali a co za tym idzie znacznie mniejszymi przekroczeniami wartości tła geochemicznego.

Średnie zawartości $\mathrm{Pb}$ w pyle drogowym były nieco niższe lub porównywalne z koncentracjami podawanymi przez Plaka i in. (2010) [17] dla gleb położonych $\mathrm{w}$ bezpośrednim sąsiedztwie tras komunikacyjnych $\mathrm{w}$ Lublinie. W przypadku $\mathrm{Cu}$ i Zn natomiast zawartości te były wyższe niż w glebach. Plak $i$ in. (2010) [17] zwracają przy tym uwagę na występowanie niższych koncentracji metali ciężkich w punktach, gdzie w ostatnich latach wykonano gruntowne remonty oraz przy nowo powstałych drogach. Porównując uzyskane w pracy dane do wyników Pasiecznej (2003) [16] dla zawartości metali w warstwie gleby $0-20 \mathrm{~cm}$, należy stwierdzić, iż koncentracje $\mathrm{Cr}, \mathrm{Cu}$ i $\mathrm{Zn}$ są wyraźnie wyższe w pyle drogowym.

\section{Podsumowanie}

W pracy dokonano analizy zawartości metali ciężkich $(\mathrm{Cu}, \mathrm{Cr}, \mathrm{Co}, \mathrm{Hg}$, $\mathrm{Mn}, \mathrm{Ni}, \mathrm{Pb}, \mathrm{V}, \mathrm{Zn}$ ) w pyle drogowym na terenie Lublina. Koncentracje wszystkich analizowanych pierwiastków z wyjątkiem $\mathrm{Hg}$ oraz $\mathrm{V}$ przekraczają wartości tła geochemicznego. Co wykazuje zawartości zbliżone do wartości tła. Koncentracje analizowanych metali ciężkich względem tła układają się według tendencji: $\mathrm{Cu}>\mathrm{Cr}>\mathrm{Ni}>\mathrm{Zn}>\mathrm{Pb}>\mathrm{Mn}>\mathrm{Co}>\mathrm{V}>\mathrm{Hg}$. Najwyższe przekroczenia względem tła odnotowano dla $\mathrm{Cu}$ i $\mathrm{Cr}$, co wskazuje na ich wyraźne bezpośrednie antropogeniczne pochodzenie (głównie transport samochodowy). Z kolei $\mathrm{Hg}, \mathrm{V}, \mathrm{Co}$, $\mathrm{Ni}, \mathrm{Zn}, \mathrm{Pb}, \mathrm{Mn}$ mają źródło pochodzenia naturalnego (gleby miejskie). Nie- 
znaczne przekroczenia wartości tła dla $\mathrm{Ni}, \mathrm{Zn}, \mathrm{Pb}$ może wskazywać na dodatkowy, umiarkowany wpływ źródeł antropogenicznych (głównie ruch samochodowy). Nie stwierdzono pozytywnych korelacji pomiędzy natężeniem ruchu samochodowego $\mathrm{w}$ miejscach poboru prób a zawartością badanych pierwiastków. Przy czym maksymalne zawartości występowały często w pobliżu miejsc o niższej płynności ruchu. Dwa główne źródła metali ciężkich w pyle drogowym na terenie Lublina: naturalne oraz antropogeniczne zostało zidentyfikowane na podstawie syntezy analizy metodą głównych składowych (PCA) oraz metody grupowania (CA) połączonych $\mathrm{z}$ analizą korelacji liniowej Pearsona. $\mathrm{W}$ oparciu o metodę głównych składowych wydzielono trzy podstawowe grupy wśród analizowanych pierwiastków z podziałem na: a) $\mathrm{Mn}, \mathrm{Zn}, \mathrm{Ni}, \mathrm{Co}, \mathrm{V}, \mathrm{Cr}$, $\mathrm{Cu}$; b) $\mathrm{Hg}$; c) $\mathrm{Pb}$. Metoda grupowania wskazuje wyraźny podział na trzy grupy: a) $\mathrm{Cr}$ i $\mathrm{Cu}$, b) $\mathrm{Pb}, \mathrm{Zn}, \mathrm{Ni}$ oraz c) $\mathrm{Mn}, \mathrm{V}, \mathrm{Co}, \mathrm{Hg}$. Na postawie analizy CA oraz PCA wydzielono pięć szczegółowszych grup o zbliżonych korelacjach i odchyleniach od tła: 1) $\mathrm{Cr}$ i Cu, 2) $\mathrm{Pb}, 3) \mathrm{Zn}$ i Ni, 4) $\mathrm{Mn}$, Co, V, oraz 5) $\mathrm{Hg}$.

\section{Literatura}

[1] Aelion C.M., Davis H.T., McDermott S., Lawson A.B.: Metal concentrations in rural topsoil in South Carolina: potential for human health impact. Sci Total Environ, vol. 402, pp.149-156.

[2] Ahmed F., Ishiga H.: Trace metal concentrations in street dusts of Dhaka city, Bangladesh, Atmos Environ, vol. 40, 2006, pp. 3835-3844.

[3] Al-Khashman O.A.: Determination of metal accumulation in deposited street dusts in Amman, Jordan. Environ Geochem Health, vol. 29, 2007, pp. 1-10.

[4] Bilos C., Colombo J.C., Skorupka C.N., Presa M.J.R.: Sources, distribution and variability of airborne trace metals in La Plata City area, Argentina. Environ Pollut, vol. 111, 2001, pp. 149-158.

[5] Chen H., Lu X., Chang Y., Xue W.: Heavy metal contamination in dust from kindergartens and elementary schools in Xi an, China. Environ Earth Sci, vol. 71, 2014, pp. 2701-2709.

[6] Miguel De E., Llamas J.F., Chacon E., Berg T., Larsen S., Royset O., Vadset M.: Origin and patterns of distribution of trace elements in street dust: unleadedpetrol and urban lead. Atmosph Environ, vol. 31, 1997, pp. 2733-2740.

[7] Han Y.M., Du P.X., Cao J.J., Posmentier E.S.: Multivariate analysis of heavy metal contamination in urban dusts of Xi'an, Central China. Sci Total Environ, vol. 355, 2006, pp. 176-186.

[8] Jaradat Q., Momani K.: Contamination of roadside soil, plants and air with heavy metals in Jordan. A comparative study, Turk J Chem, vol. 23, 1999, pp. 209-220.

[9] Kaszewski B. M.: Klimat. [w:] St. Uziak, R. Turski (red.) Środowisko przyrodnicze Lubelszczyzny. Lubelskie Towarzystwo Naukowe, 2008, Lublin, str. 75-111.

[10] Kozanecka T., Czarnowska K., Jaworska A.: Występowanie metali ciężkich w grubym pyle drogowym wokół Warszawy, Roc7zniki Gleboznawcze, tom LIV, nr 3, 2003, str. 73-78. 
[11] Kondracki J., Geografia regionalna Polski. PWN, Warszawa., 2002.

[12] Lis J., Pasieczna A., Geochemiczny Atlas Polski 1:2 500 000, Państwowy Instytut Geologiczny, Warszawa, 1995.

[13] Lu X., Wang L., Li L.Y., Lei K., Huang L., Kang D.: Multivariate statistical analysis of heavy metals in street dust of Baoji, NW China. J Hazard Mater, vol. 173, 2010, pp. 744-749.

[14] Manno E., Varrica D., Dongarra` G.: Metal distribution in road dust samples collected in an urban area close to a petrochemical plant at Gela, Sicily. Atmos Environ, vol. 40, 2006, pp. 5929-5941.

[15] Ordonez A., Loredo J., Miguel De E., Charlesworth S.: Distribution of heavy metals in Street Dust and Soil of an industrial city in Northern Spain, Environ. Contamitat. Toxicol., 2003, pp. 3949-3958.

[16] Pasieczna A.: Atlas zanieczyszczeń gleb miejskich w Polsce. Państw. Inst. Geol. Warszawa, 83s., 105 map kolor, 2003.

[17] Plak A., Bartmiński P., Dębicki R.: Wpływ transportu publicznego na zawartość wybranych metali ciężkich w glebach sąsiadujących $\mathrm{z}$ ulicami Lublina. Proceedings of Ecopole vol. 4 (1), 2010, pp. 167-171.

[18] Piontek M., Walczak B., Czyżewska W., Lechów H.: Miedz, kadm i cynk w pyle drogowym miast oraz określenie toksyczności związków tych metali metodą biologiczną, Kosmos Problemy Nauk Biologicznych, Polskie Towarzystwo Przyrodników im. Kopernika, nr 61,3, 2012, str. 409-415.

[19] Shi G., Chen Z., Xu S., Zhang J., Wang L., Bi C., Teng J.: Potentially toxic metal contamination of urban soils and roadside dust in Shanghai, China. Environ Pollut, vol. 156, 2008, pp. 251-260.

[20] Skłodowski P., Maciejewska A., Krajewska E., Szperliński Z.: Występowanie metali ciężkich w pyle opadowym na obszarach nie zabudowanych na przykładzie trasy szybkiego ruchu Warszawa-Katowice. Prace Nauk. Politechniki Warszawskiej, nr 33, 1995, str. 81-91.

[21] Walczak B.: Lead and zinc in the street dust of Zielona Góra Poland: Environmental engineering III. Pawłowski L., Dudzińska M.R., Pawłowski A., (red) Taylor \& Francis Group, London, 2010, pp. 105-113.

[22] Zhao N., Xinwei L., Shigang Ch., Xue X.: Multivariate statistical analysis of heavy metals in less than $100 \mu \mathrm{m}$ particles of street dust from Xining, China. Environ Earth Sci, vol. 73, 2015, pp. 2319-2327.

[23] Zheng N., Liu J., Wang Q., Liang Z.: Health risk assessment of heavy metal exposure to street dust in the zinc smelting district, northeast of China. Sci Total Environ, vol. 408, 2010, pp.726-733.

\section{MULTIVARIATE STATISTICAL ANALYSIS OF HEAVY METALS IN STREET DUST IN LUBLIN}

\section{S u m m a r y}

The concentrations of $\mathrm{Co}, \mathrm{Cr}, \mathrm{Cu}, \mathrm{Hg}, \mathrm{Ni}, \mathrm{Pb}, \mathrm{V}, \mathrm{Zn}$ in 49 samples of street dust from surface of traffic routes in Lublin have been studied in this work. Statistical methods such as: princi- 
pal component analysis, cluster analysis and correlation method were used to determine the sources of analyzed elements. Samples differed in trace metal concentrations. The mean concentrations of $\mathrm{Cu}$ and $\mathrm{Cr}$ were significantly higher than the background values of soil in this region $(63 \mathrm{mg} / \mathrm{kg}$ and $51 \mathrm{mg} / \mathrm{kg}$ respectively). Co, $\mathrm{V}$ and $\mathrm{Hg}$ characterize similar concentration to background values $(6,8$ and $0,03 \mathrm{mg} / \mathrm{kg})$. No clear or significant correlation between the strength of road traffic and heavy metal content in road dust sample were found. Based on multivariate statistical analysis the heavy metals have been divided into groups of diverse: natural and industry sources.

Keywords: principal component analysis, cluster analysis, road dust, trace metals, Lublin

Przestano do redakcji:30.05.2015

Przyjęto do druku:30.10.2015

DOI: $10.7862 /$ rb.2015.107 